\title{
Upaya Peningkatan Kemampuan Public Speaking Pemuda Sragi Ponorogo
}

\author{
Efforts to Increase Youth Public Speaking Ability in Sragi Ponorogo
}

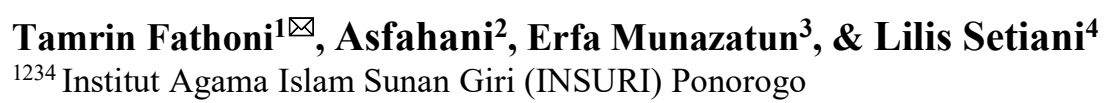

\begin{tabular}{l|r}
$\bowtie$ tam2fiana@gmail.com & Disetujui: 7 Januari 2021 \\
& Diterbitkan: 11 Januari 2021 \\
\hline
\end{tabular}

\begin{abstract}
Everyone is indeed able to speak, but only some are able to mix words into pretty rhetoric and attract the audiences. In communication studies, public speaking skills are part of effective communication, namely conveying messages to the audience in an appropriate way and attracting attention. From the reality in Sragi village of Ponorogo, there are still many youths who are less competent or not confident in speaking in public. Some of these reasons encourage the team to carry out training for public speaking skills. The purpose of this program is to assist the speaking skills of Sragi youth so that they can increase their self-confidence when presenting themselves in public. The ABCD (Asset-Based Community Development) method was employed to conduct the activity, consecutively it was found that innovative and creative training can provide new insights and knowledge about public speaking techniques among each Sragi youth. The result can be derived from this program: first, Sragi youth can do public speaking well and fluently; second, Sragi youth can arrange a certain program properly and correctly according to their needs; and third, Sragi youth have sufficient master of ceremony and public speaking skills.
\end{abstract}

Keywords: ABCD; ability; master of ceremony; public speaking; youth.

Abstrak: Setiap orang memang dapat berbicara, tetapi hanya beberapa yang mampu mencampurkan kata-kata menjadi retorika yang indah dan menarik perhatian pendengarnya. Dalam ilmu komunikasi, keterampilan berbicara di depan umum merupakan bagian dari komunikasi yang efektif, yaitu menyampaikan pesan kepada khalayak dengan cara yang tepat dan menarik perhatian. Dari kenyataan di Desa Sragi Ponorogo, masih banyak anak muda yang kurang kompeten atau kurang percaya diri dalam berbicara di depan umum. Beberapa alasan tersebut mendorong tim untuk melakukan pelatihan keterampilan berbicara di depan umum. Tujuan dari program ini adalah untuk membantu para remaja Sragi sehingga dapat meningkatkan rasa percaya diri saat tampil di depan umum. Metode ABCD (Asset-Based Community Development) digunakan untuk melaksanakan kegiatan tersebut, sehingga ditemukan bahwa pelatihan yang inovatif dan kreatif dapat memberikan wawasan dan pengetahuan baru tentang teknik public speaking di antara pemuda Sragi. Hasil yang didapat dari program ini adalah: pertama, pemuda Sragi dapat berbicara di depan umum dengan baik dan lancar; kedua, pemuda Sragi dapat menyusun agenda program tertentu dengan baik dan benar sesuai dengan kebutuhannya; dan ketiga, pemuda Sragi memiliki kemampuan MC dan public speaking yang memadai.

Kata kunci: ABCD; berbicara di depan umum; kemampuan; $\mathrm{MC}$; pemuda; public speaking. 


\section{Pendahuluan}

Banyak orang berpendapat bahwa berbicara merupakan suatu proses manusiawi yang alami, maka hal tersebut tidak memerlukan perbaikan. Pendapat ini adalah salah karena sebagaimana telah diketahui oleh khalayak bahwa berbicara yang baik dan benar merupakan suatu keahlian yang perlu dilatih. Dalam kehidupan sehari-hari, kemampuan berbicara memegang peranan penting dalam komunikasi sosial. Hal ini dikuatkan Tarigan (1998) yang menyatakan bahwa berbicara merupakan suatu alat untuk mengkomunikasikan gagasan-gagasan yang disusun serta dikembangkan sesuai dengan kebutuhan kebutuhan pendengar atau penyimak. Sholihah (2015) juga mendefinisikan berbicara sebagai keterampilan menyampaikan pesan melalui bahasa lisan. Pesan tersebut akan diterima oleh pendengar apabila disampaikan dengan nada yang runtut dan jelas.

Seseorang berkomunikasi setiap hari melalui bahasa, baik itu berbicara, menulis, ataupun mendengar, namun komunikasi yang sering dilakukan adalah berbicara. Berbicara di depan umum bukanlah hal yang mudah, diperlukan pelatihan untuk dapat berbicara dengan baik. Public speaking adalah kemampuan berkomunikasi di depan umum dengan profesional dan sistematis baik dalam komunikasi dua belah pihak maupun dalam komunikasi kelompok. Menurut Arsjad (1988), kemampuan berbicara adalah kemampuan mengucapkan kalimat-kalimat untuk mengekspresikan, menyatakan, menyampaikan pikiran, gagasan, dan perasaan. Semakin terampil seseorang dalam berbicara, maka semakin terampil dan mudahlah ia berpidato untuk menyampaikan pikiran, gagasan, dan perasaannya kepada orang lain serta semakin jelas jalan pikirannya, karena sesungguhnya bahasa seseorang itu mencerminkan pikirannya.

Berkomunikasi atau berbicara dengan orang lain adalah bagian dari rutinitas kehidupan manusia sebagai mahluk sosial. Komunikasi yang efektif sangatlah diperlukan untuk menyampaikan ide, gagasan, dan pengetahuan. Pada saat ini, kemampuan berkomunikasi kurang dimiliki oleh banyak remaja, dan takut saat mendapatkan kesempatan berbicara dan tampil di depan umum. Apalagi komunikasi saat ini dapat dilakukan secara digital dengan menggunakan berbagai aplikasi dan media sosial seperti Facebook, Whatsapp, Twitter, Line, dan berbagai platform berbasis online lainnya yang memberikan banyak pengaruh terhadap bentuk komunikasi antara individu. Tidak hanya menjadi alat komunikasi sehari-hari, namun fenomena media baru ini sudah menjadi bagian dari gaya hidup. Ditambah dengan pertumbuhan layanan internet berbasis wi-fi di berbagai tempat dan sarana umum, mempermudah proses komunikasi di antara sesama (Arifana, 2019; Cahyono, 2016; Gifary \& Kurnia N, 2015; Putri et al., 2016).

Di balik kenyamanan penggunaan aplikasi media sosial, dapat menimbulkan berbagai pengaruh buruk apabila tidak dapat membatasi diri. Menurut Suranto (2011), handphone seperti pisau bermata dua, pada satu sisi membawa kebaikan, dan sisi lainnya dapat memberikan keburukan. Salah satu pengaruh buruknya berdampak terhadap skill komunikasi pada remaja, sehingga berperilaku tertutup di lingkungan sosial, namun aktif dalam dunia maya. Selain itu, media sosial dapat mengubah perilaku individu dalam berkomunikasi (Gifary \& Kurnia N, 2015).

Ketidakmampuan berkomunikasi dapat menyebabkan seseorang tidak percaya diri ketika tampil di depan umum. Bagi mereka yang memiliki rasa takut untuk berbicara di depan publik, akan muncul rasa panik yang sangat mengganggu pikiran. Saat sebelum mulai berbicara di depan publik, tubuh yang belum siap akan mulai menunjukkan tanda-tanda awal dari reaksi panik akibat tekanan harus tampil. Detak jantung menjadi semakin cepat, telapak tangan mulai berkeringat, 
saat berdiri kepala terasa pusing dan kedua kaki gemetar. Salah satu penyebab hal ini terjadi adalah karena kurangnya pengetahuan tentang pidato, latihan dan membiasakan berbicara di depan umum (Indayani, 2013). Sedangkan menurut Wibawa et al. (2013), bagi kebanyakan orang berbicara di depan umum sangat menakutkan. Bahkan ketakutan berbicara di depan umum menduduki rangking yang lebih tinggi daripada takut pada ketinggian.

Situasi tersebut menggambarkan baik secara langsung maupun secara tidak langsung bahwa berbicara di depan umum merupakan kemampuan yang jika tidak dilatih maka akan menimbulkan gejala psikologis yang hebat pada seseorang yang belum terbiasa berbicara di depan umum. Setyonegoro (2013) mengemukakan pendapatnya mengenai hakikat keterampilan berbicara. Menurutnya, keterampilan berbicara pada hakikatnya merupakan keterampilan memproduksi arus sistem bunyi artikulasi untuk menyampaikan kehendak, kebutuhan, perasaan, dan keinginan kepada orang lain. Pengertian ini mengimplisitkan adanya peran penting bahasa sebagai sarana komunikasi.

Kemampuan berbicara menjadi tema penting, sebab dalam setiap kegiatan kemampuan berbicara memiliki peran penting. Hingga di lingkungan sehari-haripun, kemampuan berbicara adalah hal penting. Untuk itu, tim pengabdi yang terdiri dari dosen dan mahasiswa Institut Agama Islam Sunan Giri (INSURI) Ponorogo melakukan pengamatan di salah satu desa yaitu Desa Sragi Kecamatan Sukorejo Kabupaten Ponorogo, Jawa Timur. Kebetulan, hasil observasi awal menyatakan bahwa Karang Taruna di desa tersebut mengalami masalah kemampuan berbicara yang sulit, sehingga ketika ada kegiatan kerap mengalami kesulitan mencari pembawa acara (MC) dari kalangan pemuda.

Masalah keberanian pemuda dalam berbicara di depan publik ini penting, karena kondisi seperti ini jika dibiarkan maka kondisi masyarakat akan semakin tersingkirkan karena tidak ada kegiatan-kegiatan untuk penunjang kemajuan masyarakat (Harahap et al., 2020). Dengan berbagai problem yang kritis dan komplikasi di atas, maka usulan masyarakat untuk mengadakan pelatihan public speaking.

Berdasarkan survei awal yang dilakukan oleh tim pengabdi pada tanggal 3 Agustus 2020 di Desa Sragi, ditemukan gejala bahwa remaja yang tergabung dalam Karang Taruna Foksari memiliki kemampuan public speaking yang rendah. Hampir setiap mengadakan kegiatan, yang tampil sebagai pembawa acara adalah orang itu-itu saja. Padahal, yang lain pun sebenarnya memiliki kesempatan yang sama. Hanya saja, tidak adanya arahan, bimbingan, dan pelatihan bagaimana menjadi seorang public speaker menjadikan mereka enggan tampil, dan lebih memilih diam mendengarkan. Hal tersebut dapat mempengaruhi keterampilan seseorang dalam berbicara di depan umum.

Dari permasalahan di atas, tim pengabdi memiliki gagasan bahwa perlu diadakannya sebuah pendampingan agar mereka mengetahui pentingnya memiliki keterampilan public speaking dan mampu meningkatkan keterampilan tersebut. Terlebih ketika telah terjun di masyarakat, keterampilan berbicara di depan orang akan banyak diperlukan ketika menjadi MC (master of ceremony) acara RT, acara desa ataupun karang taruna. 


\section{Metode}

Metode pelaksanaan yang digunakan dalam kegiatan pengabdian ini adalah ABCD (Asset-Based Community Development), yakni suatu konsep pengembangan masyarakat yang didasarkan pada aset lokal yang terdapat di suatu wilayah. Wilayah tersebut memiliki aset yang kemudian dapat dikembangkan sehingga dapat digunakan untuk mengatasi permasalahan di wilayah tersebut. Menurut Green \& Haines (2008), dalam Asset Based Community Development terdapat 7 modal yang bisa dikembangkan: 1) modal fisik (physical capital) yang terdiri dari bangunan dan infrastruktur; 2) modal finansial (finansial capital) yang berupa dukungan keuangan; 3) modal lingkungan (environmental capital) berupa potensi alam; 4) modal teknologi (technological capital) yang berupa teknologi digital; 5) modal manusia (human capital) yang berupa sumber daya manusia; 6) modal sosial (social capital) yang berupa perilaku; dan 7) modal spiritual (spiritual capital) yang berupa pemberian bantuan empati, perhatian, dan kasih sayang.

Pengembangan modal yang menjadi fokus dalam pengabdian di Desa Sragi ini adalah modal manusia. Sedangkan langkah-langkah pelaksanaan program pengabdian ini adalah: 1) observasi lapangan; 2) koordinasi; 3) sosialisasi pelatihan; 4) pelaksanaan program pelatihan, dan 5) evaluasi.

Dalam sudut pandang metode $\mathrm{ABCD}$, keberadaan pemuda sebagai aset manusia merupakan hal yang sangat penting (Fitriawan et al., 2020). Karena fungsi pemuda sebagai aset tidak hanya sebagai modal sosial saja, namun juga sebagai embrio sosial. Aset juga bisa menjadi jembatan untuk membangun relasi dengan pihak luar. Di sini, komunitas dituntut untuk sensitif sekaligus peka terhadap keberadaan aset pemuda yang ada di sekitar mereka. Jadi, di sini Tim Pengabdi yang terdiri dari dosen pembimbing dan mahasiswa peserta Kuliah Pengabdian Masyarakat (KPM) berperan sebagai fasilitator untuk menjembatani upaya pengembangan potensi atau aset pemuda Artinya, pengembangan masyarakat dilakukan dengan keikutsertaan dari masyarakat sebagai penentu dan pelaku perubahan tersebut yang dalam hal ini adalah pemuda Desa Sragi yang menjadi aset manusia pada perkumpulan budaya karang taruna. Sedangkan tim pengabdi berperan untuk menstimulasi dan memfasilitasi masyarakat agar mau mewujudkan perubahan tersebut melalui motivasi dan pelatihan public speaking.

Dalam pelatihan ini, pemuda Desa Sragi sebagai aset manusia dibekali pengenalan materi dasar mengenai apa itu public speaking, konsep dasar komunikasi, hambatan dalam berbicara, bagaimana cara berdiri ketika akan tampil di depan umum, menggunakan gesture, kontrol vokal, tips agar tidak gugup dan berpenampilan dalam public speaking serta diperlihatkan melalui video tentang menjadi pembicara yang baik dan sukses. Setelah selesai, tiap peserta kemudian diminta mempraktikkan di depan peserta yang lain sekaligus dievaluasi oleh tim pengabdi.

\section{Pelaksanaan}

Kegiatan pelatihan public speaking bertempat di rumah Erva (anggota tim pengabdi yang juga warga Desa Sragi) yang dilaksanakan pada tanggal 14 Agustus 2020. Kegiatan ini mendatangkan peserta dari Karang Taruna Foksari Desa Sragi yang berjumlah 20 peserta. Kegiatan pelatihan public speaking memadukan teknik ceramah (pemberian materi) serta praktik langsung. Acara dimulai dengan pembukaan dilanjutkan sambutan-sambutan di antaranya oleh kepala desa dan DPL (dosen pembimbing lapangan) KPPM INSURI Ponorogo. Dilanjutkan dengan acara inti 
yaitu materi penguasaan public speaking selama 60 menit yang dipandu oleh Dosen Tamrin Fathoni dan anggota tim pengabdi lainnya.

Pertama-tama, sebagaimana dalam Gambar 1, pemateri menyampaikan tentang keterampilan berbicara, bagaimana menjadi pembicara yang baik, apa saja yang diperlukan untuk menjadi pembicara yang baik, apa saja hambatan yang mungkin muncul saat menjadi pembicara. Sebagaimana dalam maksud metode $\mathrm{ABCD}$, yakni dengan cara menggali dan mengembangkan aset dari masyarakat itu sendiri dalam hal ini pemuda Desa Sragi.

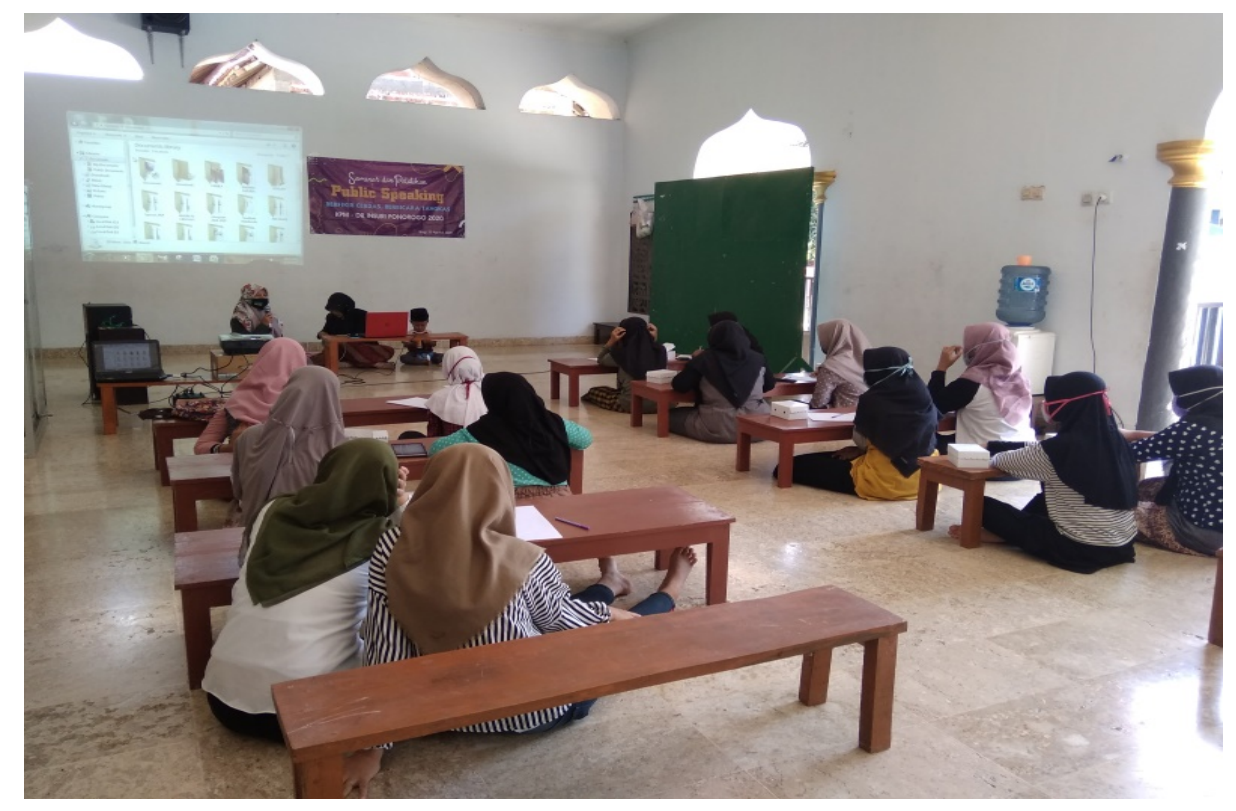

Gambar 1. Penyampaian materi public speaking

Pemateri menyampaikan materi dengan santai dan bersahabat sehingga mudah dimengerti dan dipahami serta dipraktikkan. Pemateri juga memberi motivasi dan stimulus untuk membuat peserta bergairah dan bersemangat sehingga materi yang disampaikan selama pelatihan benarbenar bisa diterapkan peserta. Berdasarkan materi tersebut, maka pemateri berinisiatif untuk mengajak ke depan beberapa peserta untuk berlatih menjadi MC, moderator, dan berpidato di hadapan teman-temannya dengan cara yang luwes (tidak kaku).

Selanjutnya, peserta diminta untuk belajar mempraktikkan sikap tubuh (gesture) yang benar dan tepat. Hal tersebut diperlukan untuk menunjang rasa percaya diri dari public speaker dan juga kesan yang baik untuk dilihat dari sisi audiens. Postur tubuh yang baik adalah berdiri tegak dengan punggung yang lurus (tidak bungkuk). Peserta diminta untuk membusungkan dada sehingga tulang punggung akan lurus dengan sendirinya. Begitu diamati, beberapa peserta terlihat malu-malu untuk latihan awal ini.

Selanjutnya, 30 menit kemudian peserta melakukan diskusi tentang materi yang sudah disampaikan dan hasil praktik pertama (Gambar 2). Setelah berdiskusi kelompok, peserta kemudian diminta kembali melakukan praktik untuk mempresentasikan hasil diskusi ke depan dengan menggunakan teknik yang telah dijelaskan sebelumnya (Gambar 3). 


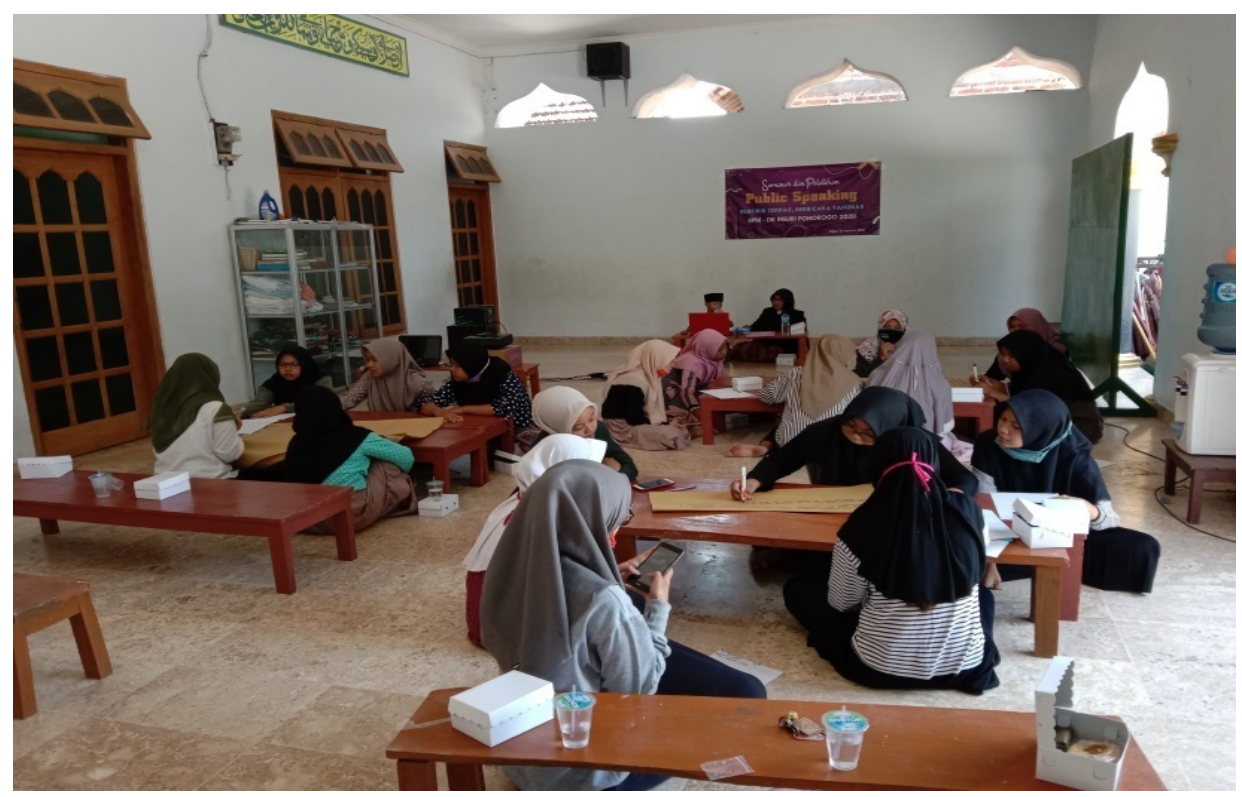

Gambar 2. Diskusi kelompok tentang materi yang sudah disampaikan

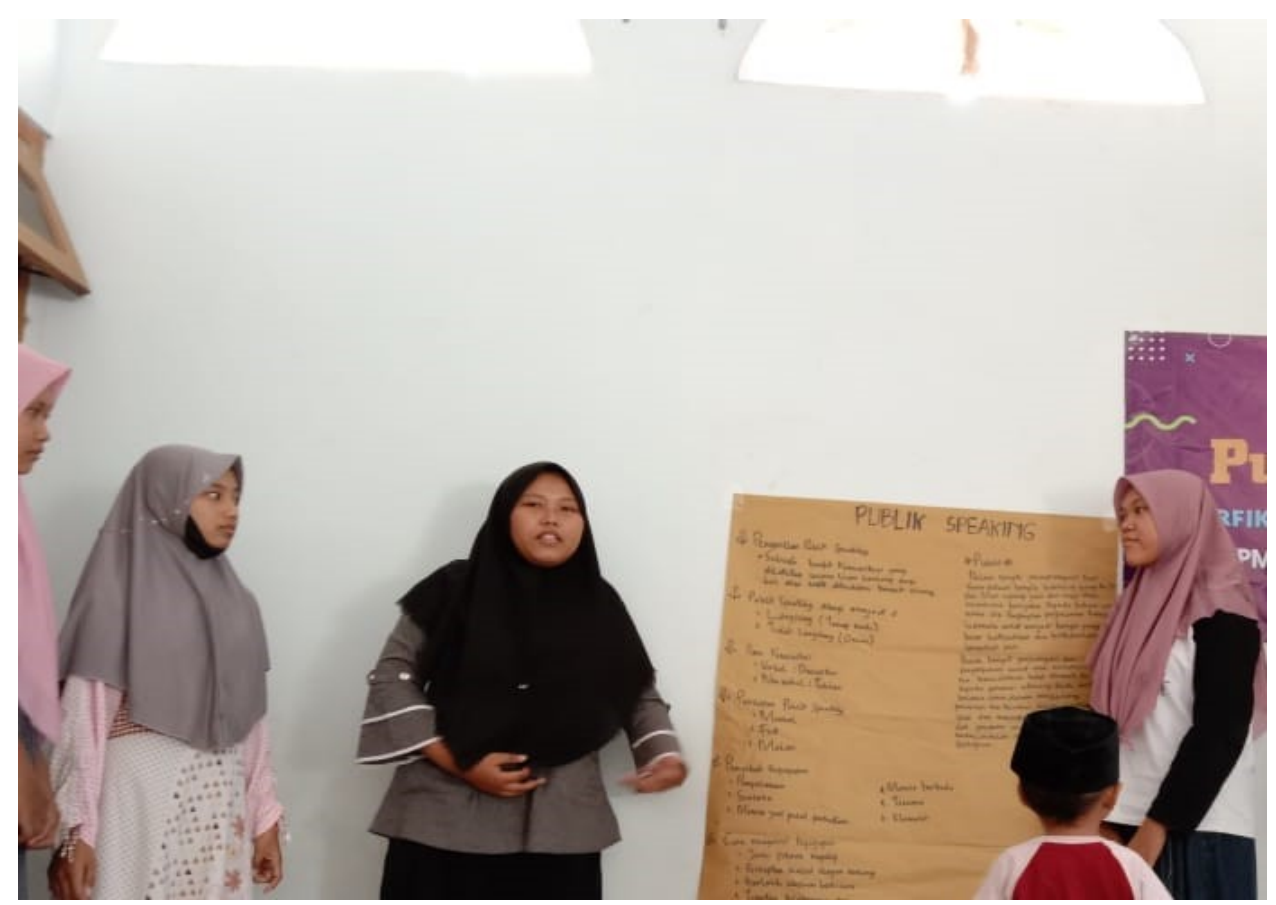

Gambar 3. Praktik public speaking secara berkelompok

\section{Dampak dan Respon Masyarakat}

Dari serangkaian acara yang telah dilaksanakan peserta memperoleh pengetahuan tentang apa itu public speaking dan cara-cara berbicara di depan umum serta penguatan mental pemuda Sragi untuk lebih berani tampil di depan umum. Proses kegiatan pelatihan berjalan dengan lancar dari proses awal agenda hingga selesainya kegiatan ini. Para peserta mampu menyerap seluruh rangkaian keilmuan yang diberikan oleh pemateri. Dari rangkaian kegiatan ini ditargetkan mampu mempraktikkan dalam kehidupan sehari-hari di tengah-tengah masyarakat desa Sragi 
Ponorogo. Dibuktikan kegiatan Agustusan para peserta mampu mempraktekkan menjadi pembawa acara dengan lancar.

Dengan demikian, pemberian materi dan praktik keterampilan dari public speaking berguna bagi audien untuk melatih kepercayaan diri dan semakin berkembang ke depannya. Terlihat dalam acara peringatan HUT RI ke-75, salah satu peserta sudah cukup baik dan percaya diri dalam membawakan acara tersebut (Gambar 4).

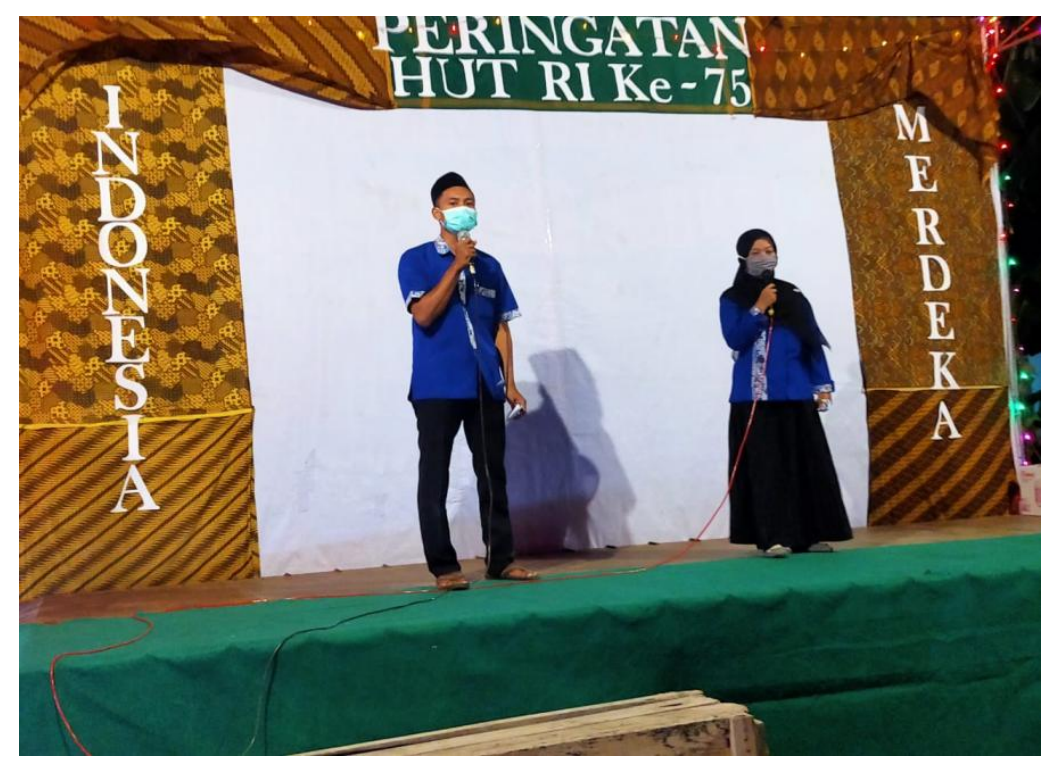

Gambar 4. Tindak lanjut praktik public speaking

Seusai pelatihan yang diselenggarakan oleh tim pengabdi, kegiatan ini mendapat respon positif dari beberapa pihak terkait dari Desa Sragi Ponorogo. Di antaranya yaitu:

1. Kateni selaku Kepala Desa Sragi Ponorogo, yang mengatakan bahwa adanya pelatihan ini sangatlah bermanfaat bagi pemuda, karena dapat meningkatkan pemahaman dan keterampilan berbicara di depan umum. Beliau pun berharap pemuda dapat menerapkan pengetahuan mengenai public speaking dengan baik.

2. Suratno selaku Ketua RT, yang juga berpendapat bahwa pelatihan public speaking sangat bermanfaat karena ketika nanti mereka maupun warga memiliki kegiatan para pemuda dapat terjun langsung membantu terlaksananya kegiatan seperti menjadi MC ataupun moderator kegiatan yang ada di lingkungan sekitar.

3. Erni, selaku perwakilan dari pemuda yang menjadi peserta public speaking, dimana mereka sangat antusias dan bersemangat untuk mengikuti seminar dan pelatihan public speaking karena mereka akan mendapatkan teknik dan solusi bagaimana cara menerapkan public speaking sesuai teori yang benar serta nantinya bisa menjadi bekal berbicara di depan umum.

\section{Analisis Manfaat Kegiatan}

Menurut Wrench et al. (2012), beberapa manfaat dalam melakukan public speaking yaitu mengembangkan keterampilan berpikir kritis, menyempurnakan keterampilan verbal dan nonverbal, dan mengatasi ketakutan berbicara di depan umum. Hal ini sangat penting diterapkan 
pada pemuda Desa Sragi Ponorogo dalam mengembangkan kemampuannya sehingga diharapkan dapat memperoleh pemuda yang kompeten.

Berdasarkan rumusan Wrench di atas, berikut juga beberapa manfaat yang didapatkan dari hasil pelatihan public speaking di Desa Sragi ini:

1. Manfaat pertama yang didapatkan setelah mempelajari public speaking adalah berpikir kritis. Demikian seseorang yang memiliki kemampuan berpikir secara kritis maka akan dapat mengidentifikasi masalah, memberikan solusi terhadap suatu masalah, memikirkan konsekuensi positif dan negatif dari solusi, serta mengkomunikasikan ide kepada orang lain.

2. Manfaat yang kedua dalam mempelajari public speaking adalah membantu menyempurnakan kemampuan komunikasi verbal dan non verbal. Komunikasi verbal adalah bentuk komunikasi yang disampaikan komunikator kepada komunikan dengan cara tertulis (written) atau lisan (oral), ide-ide, pemikiran atau keputusan, lebih mudah disampaikan secara verbal ketimbang non verbal. Sedangkan komunikasi non verbal adalah merupakan kebalikan dari komunikasi verbal yakni suatu proses komunikasi atau penyampaian pesan maupun informasi yang disampaikan oleh seseorang kepada orang lain tanpa adanya suatu ucapan atau kata-kata, melainkan menggunakan gerakan isyarat.

3. Manfaat ketiga dalam mempelajari public speaking adalah mengatasi rasa takut berbicara didepan umum. Beberapa orang mengalami kecemasan berlebih saat berbica didepan umum, dengan mempelajari teknik public speaking maka pembicara akan dapat melakukan public speaking dengan baik dan terhindar dari rasa takut, cemas, grogi, dan stres.

Berdasarkan ketiga manfaat di atas, maka dapat disimpulkan bahwa public speaking sangatlah penting guna meningkatkan keterampilan berbicara di depan terutama dalam kegiatan karang taruna di Desa Sragi Ponorogo. Maanfaat public speaking yang lain bagi pemuda adalah meningkatkan kemampuan komunikasi, meningkatkan kemampuan organisasi, membantu mengontrol emosi, meningkatkan memori, meningkatkan kepercayaan diri dan sebagai bekal untuk kehidupan mendatang.

Dengan adanya seminar dan pelatihan public speaking ini komunikasi para pemuda karang taruna menjadi lebih produktif dan berani tampil di depan umum. Hal ini dibuktikan dengan adanya MC dalam kegiatan rutinan karang taruna. Para pemuda yang awalnya tidak percaya diri dilatih dan dibiasakan berbicara di depan umum dalam kegiatan tersebut.

\section{Kesimpulan}

Hasil kegiatan pelatihan public speaking karang taruna bagi pemuda Desa Sragi Kabupaten Ponorogo ini memberikan manfaat khususnya bagi pemuda yang menjadi aset masyarakat setempat. Adapun manfaat setelah mengadakan pelatihan di antaranya mereka mampu berpikir kritis dan berani, membantu menyempurnakan kemampuan komunikasi verbal dan non verbal, dan mengatasi rasa takut berbicara di depan umum. Ke depannya, Karang Taruna Foksari sudah tidak lagi memiliki kekhawatiran terhadap berbagai permasalahan khususnya dalam mengadakan sebuah acara atau kegiatan. 


\section{Pernyataan}

Tim penulis sekaligus pengabdi mengucapkan terima kasih kepada Kepala Desa, Ketua RT, dan Pemuda Karang Taruna Foksari Desa Sragi Kecamatan Sukorejo Kabupaten Ponorogo, serta tokoh masyarakat dan segenap warga desa tersebut. Dengan dukungan dari semuanya, pengabdi dapat melaksanakan kegiatan ini dengan lancar.

\section{Referensi}

Arifana, A. (2019). Pengaruh Penggunaan Facebook Terhadap Perilaku Komunikasi Siswa. Persepsi: Communication Journal, 2(2), 11-45. https://doi.org/10.30596/persepsi.v2i2.3940

Arsjad, M. (1988). Pembinaan Keterampilan Berbicara Bahasa Indonesia. Erlangga.

Cahyono, A. S. (2016). PENGARUH MEDIA SOSIAL TERHADAP PERUBAHAN SOSIAL MASYARAKAT DI INDONESIA. PUBLICIANA: Jurnal Ilmu Sosial Dan Ilmu Politik, 9(1). http://jurnal-unita.org/index.php/publiciana/article/view/79

Fitriawan, F., Rohmatulloh, D. M., Asfahani, A., \& Ulfa, R. A. (2020). Pemberdayaan Ekonomi Pemuda Melalui Budidaya Jamur Tiram di Dusun Sidowayah, Kecamatan Jambon, Kabupaten Ponorogo. Amalee: Indonesian Journal of Community Research and Engagement, 1(01), 47-58. https://doi.org/10.37680/amalee.v1i01.187

Gifary, S., \& Kurnia N, I. (2015). INTENSITAS PENGGUNAAN SMARTPHONE DAN PERILAKU KOMUNIKASI (Studi Pada Pengguna Smartphone di Kalangan Mahasiswa Program Studi Ilmu Komunikasi Universitas Telkom). Jurnal Sosioteknologi, 14(2), 170 178. https://doi.org/10.5614/sostek.itbj.2015.14.2.7

Green, G. P., \& Haines, A. (2008). Asset Building and Community Development (2nd ed.). Sage Publications.

Harahap, E. M., Hasibuan, S., Afifah, N., \& Lubis, K., (2020). PEMBINAAN KETERAMPILAN BERBICARA PRODUKTIF PADA NASYIATUL AISYIYAH RANTING BATU NADUA SITAMIANG. In PROSIDING SEMINAR NASIONAL HASIL PENGABDIAN (Vol. 3, Issue 1). https://e-prosiding.umnaw.ac.id/index.php/pengabdian/article/view/498

Indayani, I. (2013). Peranan Pembimbing Kegiatan Public Speaking dan Kepercayaan Diri Siswi di Pesantren Darul Hikmah Medan Iin Indayani. In FLOW (Vol. 2, Issue 4). https://jurnal.usu.ac.id/index.php/flow/article/view/11291

Putri, W. S. R., Nurwati, N., \& S., M. B. (2016). PENGARUH MEDIA SOSIAL TERHADAP PERILAKU REMAJA. Prosiding Penelitian Dan Pengabdian Kepada Masyarakat, 3(1). https://doi.org/10.24198/jppm.v3i1.13625

Setyonegoro, A. (2013). HAKIKAT, ALASAN, DAN TUJUAN BERBICARA (Dasar Pembangun Kemampuan Berbicara Mahasiswa). Pena: Jurnal Pendidikan Bahasa Dan Sastra, 3(1), 67-80. https://online-journal.unja.ac.id/pena/article/view/1451

Sholihah, R. A. (2015). Metode Suggestopedia dengan Teknik Bermain Peran atau Role Playing dalam Pembelajaran Keterampilan Berbicara Bahasa Indonesia siswa Sekolah Dasar. AlAdabiya: Jurnal Kebudayaan Dan Keagamaan, 10(1), 1-24.

Suranto, A. W. (2011). Komunikasi Interpersonal. Graha Ilmu.

Tarigan, H. G. (1998). Berbicara Sebagai Suatu Keterampilan Berbahasa. Angkasa. 
Wibawa, A. A., Sarwoko, S., Sugiharto, C. E., \& Suciska, W. (2013). PELATIHAN DASAR PUBLIC SPEAKING (PELATIHAN BAGI PEGAWAI NEGERI SIPIL DAN TOKOH MASYARAKAT DI WILAYAH DESA TAMAN BOGO KECAMATAN PURBOLINGGO, LAMPUNG TIMUR). Seminar Hasil-Hasil Penelitian Dan Pengabdian Kepada Masyarakat.

Wrench, J. S., Goding, A., Johnson, D. I., \& Attias, B. A. (2012). Public Speaking: Practice and Ethics. https://2012books.lardbucket.org/books/public-speaking-practice-and-ethics/ 